\title{
Taxis and crowd-taxis: sharing as a private activity and public concern
}

\author{
Merethe Dotterud Leiren \\ Center for International Climate and Environmental Research (CICERO), Oslo, Norway, \\ merethe.leiren@cicero.oslo.no
}

\section{Jørgen Aarhaug}

Institute of Transport Economics, Oslo, Norway, jorgen.aarhaug@toi.no

Published on 30 Jun 2016 | DOI: 10.14763/2016.2.420

\begin{abstract}
The sharing economy has generated interest among economists for its customer focus and potential to enhance competition. However, it has also caused uproar in industries which have felt competitive pressure, for example among the established stakeholders in the taxi industry. While regulations currently impose considerable costs on the taxi industry, they do not cover virtual transport innovations such as Uber. The lack of a level playing field between taxis and such 'crowd-taxis' has generated media attention and conflict. Taxi owners worry about decreasing revenues and taxi drivers about poor working conditions. Other concerns are related to poor transport preparedness, accessibility issues, quality assurance and tax evasion. Despite considerable media attention, there has so far been a lack of scholarly literature addressing the consequences of the sharing economy in the transport sector. Focusing on the Norwegian taxi market, we argue that crowd-taxis will likely produce a range of unanticipated effects, necessitating regulation. For example, crowd-taxis may contribute to a loss of transport preparedness in rural areas. The findings are based on first and secondary data and 19 interviews.
\end{abstract}

Keywords: Sharing economy, Transport, Crowdworking

\section{Article information}

Received: 01 Feb 2016 Reviewed: 12 Apr 2016 Published: 30 Jun 2016

Licence: Creative Commons Attribution 3.0 Germany

Competing interests: The author has declared that no competing interests exist that have influenced the text.

URL:

http://policyreview.info/articles/analysis/taxis-and-crowd-taxis-sharing-private-activity-and-public-con cern

Citation: Dotterud Leiren, M. \& Aarhaug, J. (2016). Taxis and crowd-taxis: sharing as a private activity and public concern. Internet Policy Review, 5(2). https://doi.org/10.14763/2016.2.420

This paper is part of Regulating the sharing economy, a special issue of Internet Policy Review guest-edited by Kristofer Erickson and Inge Sørensen. 


\section{INTRODUCTION}

The sharing economy is rapidly affecting different transport markets. One such sector is the taxi industry, where strict regulations impose high costs on the operators and favour the operators that are already in the market. Given the disintermediating effects of new technologies such as smartphones and social media, new service providers impose considerable competition to the existing taxi services. These new operators are 'crowd-taxis' which make use of web applications including myTaxi, Taxi Magic and Uber. In interviews, representatives of these firms argue that they want to be viewed as something different from a taxi service. While offering services that are similar to taxis, crowd-taxis are actors 'outside' the regulated taxi industry. Several researchers emphasise the benefits of such innovations, arguing that they are likely to do a better job of serving consumer needs than traditional services - therefore bringing into question the need for much of the existing regulation (Koopman, Mitchell \& Thierer, 2014). However, historically taxi regulations have contributed to 'tidying' up the market, pushing operators in the 'grey' area into the 'white' economy (Fagerli, Strømsnes \& Langli, 2000). Taxis provide important services for the society as a whole, including 24-hour preparedness and transport services where there may otherwise be no public transport. Taxi policies play an important role in ensuring for example, customers' safety. We therefore ask the question: what are the effects of these new transport innovations on traditional taxi services?

While cities are attractive markets in terms of being profitable for transport providers, rural areas are usually considered less profitable because of longer travel distances. The effects on taxi services and related impacts for society and welfare may therefore vary across areas. A study of the transport sector in Norway is relevant because it is a large country in terms of area (385,000 square kilometres) with a relatively small population (5.2 million people), living in cities and many small, rural municipalities.

Including issues of quality, safety and preparedness, this study contributes to improved understanding of the border between 'sharing' as a private activity and public concern. To study this transport sector is interesting as the topic has been widely cited as an example of the effect of the sharing economy by the media, but - with few exceptions (Cohen \& Sundararajan, 2015) - remains under-analysed.

The roadmap is as follows. First, we provide useful insights from the literature to understand the effects on the transport market and society. Second, we present the data that we use. Third, we describe the different transport services, both traditional taxi services and innovations. Fourth, we present the views and concerns of providers. Fifth, we discuss the implications of innovations for the taxi market and society. Finally, we conclude that virtual crowd-taxis contribute to strengthening a tendency of weakening revenue base among taxi owners and creating an unlevel playing field. Deregulating the taxi market so that virtual crowd-taxis have access will contribute to a loss of transport preparedness in rural areas with consequences for accessibility. Currently, traditional taxis cover such transport needs. The decreasing revenue base and the structure of the sharing economy incentive scheme leads to gaps in coverage, as drivers will tend to go to more high-paying zones only. Therefore, there might be a need for local public authorities to provide for such transport preparedness. 


\section{THEORETICAL PERSPECTIVES}

The aim of this section is twofold: first, we present Rob Shield's perspective of virtual technology to create a frame for understanding the taxi sector as such in the context of virtual technologies. This is useful as taxis are typically treated as part of the transport sector and rarely within the field of virtual technology. Second, in order to explore the impacts of crowd-taxis on the taxi market and related societal effects, we draw on contributions related to the post-fordist service economy and professionalisation theory.

The concept of the virtual is relevant as information technology contributes to dramatic changes in economics and everyday life. In his work on the virtual, Rob Shields (2003) identifies some of the different beliefs and fears that have surrounded computer technology. He defines virtual as 'real but not concrete' (p. 2, italics in original). He argues that: 'To describe something as "virtual" indicates that it is not strictly according to definition, as in a "virtual office", which is to say not literally an "office" as one might understand an office to be, but an office "in effect" (p 23). In other words, ontologically the virtual office is real in purpose and effects, although not 'concrete'. Shields argues that a physical office (or organisation) is related to a place. However, the network on the internet precedes even virtual space, allowing for flexible work among employees and an agile and responsive organisation (p. 118). Shields suggests that first, information technology replaces old technologies but in existing ways of working. For example, taxi companies make use of similar technologies as crowd-taxis, yet taxis continue to operate more or less in the same way as before. Shields argues that the more important implications occur when expertise and enterprises across time and space intermingle (p. 119), giving businesses the opportunity to combine jobs and cluster work tasks (p. 147). Shields provides a thorough historical analysis of the virtual. However, he does not make 'the virtual' a key aspect of the modern networked society (see Kellner and Thomas, n.d.).

In contrast, researchers and interest groups focusing on crowdsourcing and crowdworking in the post-fordist service economy suggest that virtual technologies have resulted in a shift of paradigm (see Felstiner, 2011, p. 145). Describing how in the age of the internet companies arose to take advantage of the networked world in search of cheaper labour, Wired Magazine journalist Jeff Hove, introduced the label 'crowdsourcing'. He wrote, 'Technological advances [...] are breaking down the cost barriers that once separated amateurs from professionals. [...] The labor isn't always free, but it costs a lot less than paying traditional employees. It's not outsourcing; it's crowdsourcing' (Hove, 2006). Hove pointed out that established businesses were taking advantage of the online connected crowd. Although crowdsourcing has increased remarkably during the last decade, it is still relatively new. Hove's focus was on paid crowdsourcing. There is also voluntary, unpaid crowdsourcing, which refers to people sharing for example, their capacity or knowledge for free, and contribute to common goods or noncommercial work.

Alek Felstiner (2011) defines crowdsourcing as 'the process of taking tasks that would normally be delegated to an employee and distributing them to a large pool of online workers, the "crowd," in the form of an open call' (p. 143). He compares crowdsourcing with domestic subcontracting, temporary staffing and outsourcing of products. The crowdsourcing 'middlemen', for example the owners of the Uber application, exercise some kind of control over the workers and obtain revenue (p. 149).

Authors (e.g., Felstiner, 2011; Cohen \& Sundararajan, 2015) point out the positive aspects 
related to crowdsourcing for workers. One key advantage is the flexibility for the worker to work when, where and how long s/he wants to and the freedom to choose tasks. They also highlight the low barriers to enter and exit different markets, as an internet connection is 'all' a crowd worker needs, which bears the potential to create new labour markets. Such opportunities spread optimism about work possibilities in areas without sufficient labour markets for example, in rural areas.

However, researchers highlight several issues related to crowd work. First, the wages are frequently low, there are no benefits and job security is lacking. The employment relationships are usually fleeting and the workers do not enjoy legal protection. Second, there are concerns about market failures due to information asymmetry and negative externalities (Cohen \& Sundararajan, 2015). Related to asymmetric information, a buyer may not know the quality of the work. Such uncertainty may result in less transactions than what is socially optimal (Cohen \& Sundararajan, 2015, p. 120). However, as Cohen and Sundararajan (2015) suggest, increasingly software solutions dependent on exchange of experiences among users are grappling with reputation of workers as a way of quality assurance. Moreover, the choices made by a buyer or provider may create negative externalities, i.e. imposing costs on others. An additional taxi vehicle on the road may contribute to congestion and increasing emissions due to more empty driving, i.e. driving without passengers (Cohen and Sundararajan, 2015, p. 122).

Another perspective, which may be relevant to understanding the effect of virtual technology on the transport sector is professionalisation theory, since crowd-taxis can be offered by anyone. A profession is a job that requires special education, training or skills. Modes of training or preparation for a profession contribute to keep knowledge within the occupational group, while standards help maintain the reputation of competent practitioners (Eraut, 1994, p. 6). Moreover, the workers' power and status are dependent on their ability to claim that their expertise is unique, i.e, it is not shared with other groups (Eraut, 1994, p.14). However, Eraut (1994) argues that traditional accounts of professionalism is becoming outmoded. Addressing services, he suggests that there has been a change in focus from profession to the client. He suggests that while there has been a growing distrust of scientific and technical knowledge, client needs and rights have increasingly gained acceptance. Politicians have therefore sought to regulate professional work to a larger extent. Similarly, the service-dominant logic of marketing suggests that the web-wired world reconnects supply and demand of services in new ways which increases the focus on the consumer further (Ballantyne \& Varey, 2008). Concern for citizens' rights and the increasing cost of public services has given rise to the potentially conflicting aims of efficiency, effectiveness, economy, responsiveness and quality. Extending this argument, we could expect virtual technologies to contribute to break down in certain professions, if such technologies make it easier for people, who are not part of a profession, to deliver such services.

\section{DATA AND RESEARCH TECHNIQUES}

The analysis draws on primary and secondary data, with the former gathered through 19 interviews in two rounds. First, seven interviews took place in late 2014 and early 2015 as part of a study of the taxi services in Buskerud county. Second, during the second half of 2015 and early 2016 we carried out 12 supplementary interviews for the purpose of studying the sharing economy (see Appendix). The interviewees include the management (CEO or regional director) of five taxi companies, which operate as dispatchers and providers of taxi services in Oslo and Drammen (Oslo Taxi, ByTaxi, Star Taxi, Drammen Taxi and Norgestaxi Buskerud). They include representatives for the regional licensing authorities in Oslo and Akershus counties and the 
management of both small and large dominating dispatchers.1 Other interviewees are the market director of the ride-sharing service GoMore and the chairman of the board and chief advisor of the Association of Norwegian Taxi Owners, which represents more than half of the registered taxi owners in Norway, and the general manager and market manager of Uber Norway. We have gathered information from taxi drivers (one owner operator and three employed drivers) and four crowd-taxi drivers (i.e. Uber drivers). Representing different organisations or interests, the respondents provide different opinions and perceptions rather than a representative view.

All the interviews took place in and had a key focus on Drammen (in Buskerud), which is located $40 \mathrm{~km}$ southwest of Oslo and has 115,000 inhabitants, Oslo with 960,00o inhabitants and the county Akershus surrounding Oslo with 600,000 inhabitants. In addition to being the largest taxi market in Norway, Oslo stands out, as it is the only city in Norway where Uber has established itself. In contrast, the counties Akershus and Buskerud are relevant because they have urban and large rural areas. This is of particular interest as the taxi market is different in urban and rural areas, with public service obligations being much more important in rural areas (see Aarhaug, 2015).

The secondary data (Aarhaug, 2015; Aarhaug \& Osland, 2010; Aarhaug \& Skollerud, 2014; Longva, Osland \& Leiren, 2010) is important because it provides nationwide insights. While this data has been published in Norwegian research reports, much of this information is not accessible in English.

\section{THE NORWEGIAN TAXI MARKET}

The rapid growth of information technology in society has created new opportunities and challenges in the passenger transport market. Through a mobile application, passengers may request services not only from taxis and ordinary public transport, but from drivers who offer taxicab-like urban transportation in hundreds of cities all over the world. Applications such as Uber, Lyft, myTaxi, Taxi Magic and Sidecar offer considerable competition to traditional taxi companies. Among the companies using mobile phone technology to offer passenger transport, Uber is the most visible. Currently only UberPop and UberBlack exist in Norway. While UberBlack is for linking customers with professional limousine drivers, UberPop links passengers to drivers without professional taxi licenses or chauffeur training. In this section we describe the differences between conventional taxis and what we call 'crowd-taxis', i.e. transport made possible via such applications and functioning outside existing taxi regulations. We use the term crowd-taxis and not virtual taxis as conventional taxis also make use of virtual technologies. We focus on UberPop, as there are no particular controversies related to UberBlack. However, it is of interest that UberBlack has resulted in stricter entry regulation for limousine services in Oslo. The regulating authorities prefer to limit the use of limousines as taxis (Interview 19). In the following, we explore the possibilities and challenges that arise with virtual transport innovations such as UberPop.

Jørgen Aarhaug and Kåre Skollerud (2014) define a taxi as 'a vehicle with a driver available for hire for the general public' (p. 277). They argue that this definition is useful as it captures a variety of taxi characteristics in different cities. However, with the arrival of the mentioned innovations, such a broad concept runs into several issues related to when a taxi ceases to be a taxi, what the boundary markers of legitimacy between taxis and crowd-taxis are, as well as whether the boundaries are malleable. The new transport services made possible via mobile 
applications fall into Aarhaug and Skollerud's definition. However, several innovation characteristics help us distinguish the new services from conventional taxis. The definition is therefore not relevant in discussions of the sharing economy - at least as long as the current legislation remains. In the following, we highlight five characteristics that distinguish taxis from crowd-taxis.

One distinction is related to taxi permits. In Norway every taxi owner needs to have a taxi licence, which is a needs-tested permit to offer taxi services in a given area. There is one such permit per car and taxi owner, who might employ a couple of drivers. The regional administrations are the responsible public authorities for providing such permits. Therefore it varies across regions how competitive the taxi market is. The key policy behind the Norwegian needs-testing policy is related to protection of the existing taxi providers: it is to ensure that taxi services are offered in areas and at times, where and when such services would otherwise not exist due to lack of profitability (see Longva, Osland \& Leiren, 2010). The public authorities limit the access to the taxi market in order to keep random car owners from 'cream skimming' in good transport markets, thereby eliminating business possibilities in less favourable times and areas. Furthermore, the needs-testing of taxi permits gives the public authorities an opportunity to require driving and coverage obligations to ensure access to taxi services at all times (24 hours) at reasonable prices and other quality requirements (Longva, Osland \& Leiren, 2010). In contrast, there are no similar regulations addressing virtual devices. Although Uber facilitates for transport, connecting drivers and passengers with each other, Uber does not provide transport services itself. This raises the question of the level and the objective regulation should address: whether the cloud efficiencies and pricing algorithms introduced by Uber may overcome the challenges created by the difference between profitability for the taxi driver and society's demand for distribution of service in time and space (see Aarhaug and Skollerud, 2016).

Another distinction is related to the status of the professional versus the non-professional. In order to offer passenger transport services - which are not regular, the Norwegian professional transport law requires that the driver has a taxi permit. In addition to a driving license, a taxi driver has to have good conduct (i.e. a certificate from the police stating that the driver is allowed to drive commercially), adequate professional competence (i.e. local knowledge as tested via local taxi exams) and satisfactory financial capability. These requirements give the public authorities the possibility to control the services: the police controls the permission to conduct vocational transport; the tax authorities control the financial viability and the regional public authorities regulate the permits. In contrast, an Uber driver could be anyone.

On several occasions, the police has arrested and fined non-taxi drivers in Stavanger and Oslo, including both Haxi and Uber drivers (Moe, 2015; Riaz, 2015). Given the taxi permit requirement in the professional transport law, police lawyers interpret the services offered by Uber drivers as illegal 'private taxis'. Awaiting legal actions, commercial taxis therefore experience some protection from the competition of non-regulated market entrants.

A third distinction is related to employment. While a taxi driver is either the taxi owner her/himself or the employer of perhaps a couple of drivers, Uber drivers do not have an employer. Uber drivers are independent contractors who pay a percentage of their fares to Uber. Similarly, the traditional taxi dispatcher does not employ drivers. However, the taxi dispatchers require that the taxi owners, who either own or have contracts with a dispatcher, employ a sufficient number of drivers to be able to provide the services that they are responsible for (e.g. driving and coverage obligations), thereby ensuring transport preparedness. This preparedness is 
incorporated into the taxi dispatchers' regulations. This requirement to be on duty at all times has contributed to ensure the taxi owner's income for living (Longva, Osland \& Leiren, 2010, p. 20). However, 'to always be ready to drive, and never be able to party' may also contribute to making the profession less popular in particular in rural areas, where there may be only one taxi owner and not many connected to a large dispatcher. In contrast, the Uber drivers are free to work as much or as little as they want. They are not obliged to drive, although there may be a transport need; for example, a woman in labour who needs urgent transport to the hospital. Moreover, the drivers themselves are not guaranteed a livelihood from being Uber drivers and their insurance benefits are lower than for taxi drivers. Yet the Norwegian Competition Authority (2015) suggests that the opportunity to be a driver as a second job may make it more attractive to deliver transport services also in rural areas.

A fourth distinction is that it is compulsory for taxis to use taximeters related to payments. These are subject to quality controls. In the city of Oslo, the dispatchers can set their own fares, but the fare schedule is set (a flag fall, and a price per kilometre and minute). In contrast, an Uber vehicle does not have a taximeter. The billing is done via smartphone and the fare structure is dynamic.

A fifth distinction refers to different market segments. Figure 1 highlights a number of transport segments (see also Longva, Osland \& Leiren, 2010). The existence or importance of the market segments vary with geographical characteristics. Dense cities have relatively high activity on the street hire and curb/rank market segments, while the pre-book segment dominates in less dense cities. Equally, the size of different contract segments varies with geography: the share is larger in rural areas (Aarhaug, 2015). The share is considerable also in cities; for example, in Drammen 40 percent of the turnover comes from contracts with public authorities (Aarhaug \& Osland, 2010). Such contracts include special transport services for educational purposes, people with disabilities, people of old age and patients. The contracts include accessibility requirements; for example, part of the vehicle fleet has access for wheelchairs.

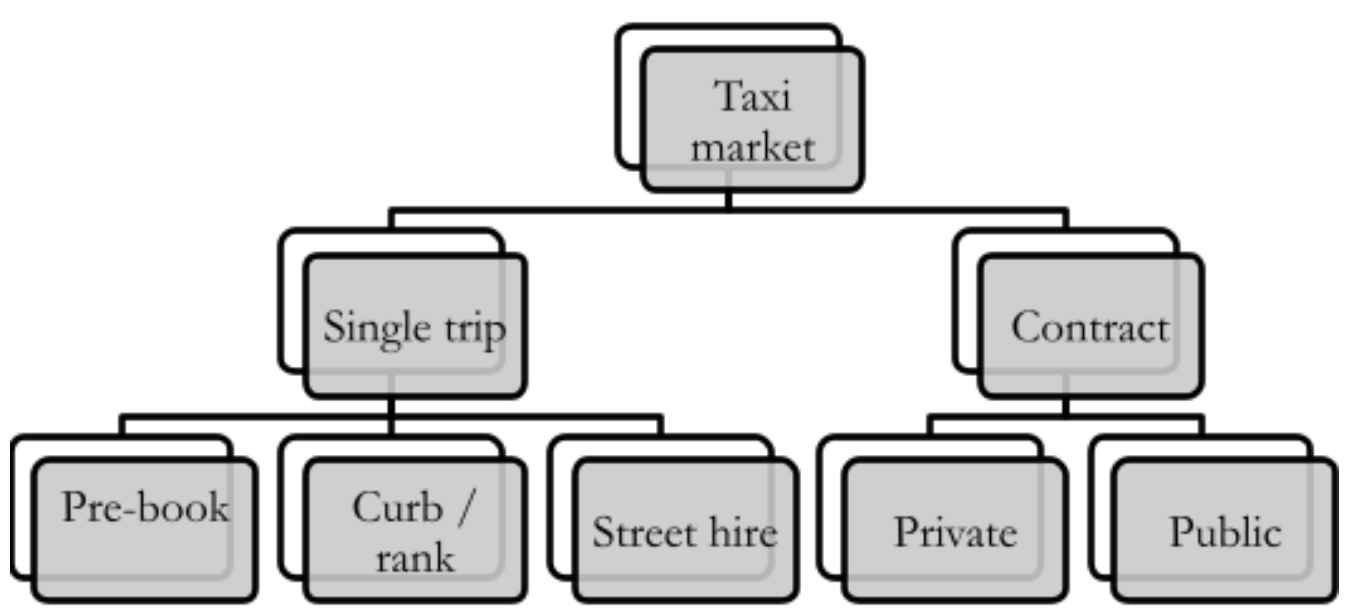

Figure 1. Taxi market segments

While conventional taxi services cover all the segments, the new transport services that have arisen with the virtual technologies are particularly interested in the pre-booked, single trip segment. In this 'non-contract' market, information technologies are decisive for arranging transport. Automation and streamlining of connecting drivers and passengers with each other 
contribute to user and operator benefits. Such possibilities reduce the marginal cost by eliminating manual handling, making it possible for the provider to offer the same services as conventional taxis at a lower price or with higher profits. In comparison to the other segments, the pre-booked, single trip market is more price sensitive (Rose \& Hensher, 2013). The lower prices make the crowd-taxis attractive for relevant passengers.

In general, Norwegian consumers perceive taxi fares as being too expensive (The Consumer Council, 2015a). In rural and small urban areas the 24-hour service obligation is the most costincreasing factor. In rural areas fares are regulated by law with given maximum prices. Large urban areas do not have such price regulation. In many rural areas one consequence of the price regulation is customer queues, as there are not enough taxis at demand peaks. Another is crosssubsidisation from services delivered to the public authorities for special transport services, i.e. contract based services.

A sixth distinction concerns the 'middle man', which is a dispatcher or a mobile phone application. While hailing a taxi from the street or a taxi stand only requires a driver and a vehicle on the supply side, pre-booked trips usually require a dispatcher. A dispatcher coordinates trips and connects supply (i.e., driver and vehicle) with transport demand (i.e. the passenger). Historically dispatcher services have been conducted by a person with a phone, radio and post-it notes. Since the early 1990 dispatchers have made use of computers, with software that optimises the services.

Internationally there is a lot of variation in how dispatchers are regulated. In Oslo, it is compulsory for every taxi license holder to be associated with one of the dispatchers. Currently this number is five, but this fluctuates, as anyone can open a new dispatcher, given that they adhere to a set of criteria. Prior to 2015, when the taxi regulation in Oslo was introduced, political approval was necessary in order to establish a new dispatcher. Currently, no dispatcher is allowed to have more than 50 percent of the taxi licenses, in order to limit market domination. In contrast, crowd-taxis are not connected to traditional taxi dispatchers, but web applications such as Uber operate as middlemen.

The mentioned six points suggest that Uber drivers have certain competitive advantages in comparison to conventional taxi owners in the pre-booking and hailing markets. The administrative and fixed costs required for entering new geographical markets are small for Uber drivers as compared to traditional taxi dispatchers, where the taxi owner is obliged to enter several different market segments. On the one hand, the differences in regulation and obligation have created concerns among taxi owners, taxi drivers and the regulating authorities about the lack of a level playing field between taxis and non-taxi service providers (Interview $1 ; 7 ; 11 ; 19$ ). The demand from the taxi industry is to create a level playing field - 'then we'll beat them' (Interview 1; Tobiassen, 2016).

On the other hand, there are voices speaking in favour of the web-based transport services. Private cars represent underused capital. Uber drivers include drivers whose Uber activities is their principal source of income: 'Uber is my main source of income, while I am applying for other jobs and as I have finished my studies this spring' (Interview 15). Several drivers only offer such transport services as a part time activity, offering their services in high-demand periods, 'We have many drivers, but few hours per person' (Interview 2). They are ordinary car owners, who have signed up on the web to transport passengers. This use of part time vehicles in high demand periods contributes to increasing efficiency, as the demand for taxi services fluctuates considerably throughout the week. 'Our demand curve fluctuates even more than that of traditional taxis' (Interview 2). Moreover, Uber drivers can make use of adoptive pricing. They 
can stimulate the supply by charging higher fees in peak periods and using lower prices in offpeak periods. This has been controversial as the high peak fare or 'surge pricing' is considered as being unfair, although it improves efficiency (see Tucker, 2014).

None of the informants express negative attitudes towards Uber's technology. Uber drivers suggest that they 'enjoy the app' (Interview 13; 14; 15). Similarly, taxi dispatchers, owners and drivers highlight the benefit of smartphone based technologies (Interview $5 ; 6 ; 8$ ). They do not fear the technology itself - it is the unfair treatment between taxis and crowd-taxis in being 'allowed' to use such technology that creates concerns.

One feature of the sharing economy is that it often adopts altruism as a motivation to participate. The idea is that the owner of the available capacity offers this capacity for a small amount of time. As the capacity is available, sharing it makes everyone better off (even independent of any transactions which occur between parties). The understanding is that Uber drivers are in a sense carrying out favours when sharing their vehicle and time. Similarly, there are examples of young people using social media to tell their friends, 'I'm driving tonight, if anyone needs a ride.' However, UberPop does more than only 'sharing' their rides. Taxi interests highlight the economic aspects: 'this is not sharing, this is operating outside the regulated economy. It is not altruism to drive and not pay taxes' (Interview 17). It is disputed whether the exchange of money for labour, provided by independent contractors can be labelled 'sharing' (Kessler, 2015).

Furthermore, one of Uber's aims in Norway is to make it unnecessary for people living in the city centre to own their own car (Eggesvik, 2015). This way Uber is part of a mobility concept, where what is important is to get to a destination as quickly and smoothly and possible - not to get there in your own car. In this way Uber similarly links itself with normative social objectives such as 'clean' or 'smart' cities.

However, a key concern among service providers, and regulating authorities, is that crowd-taxis only provide services when profitable to the driver. Over time, they suggest that this will result in loss of service in time periods and areas, which are not lucrative for example, rural areas (Interview $1 ; 17 ; 18$ ). While today's taxi regulation requires coverage in areas and at times where these services are not profitable for the taxi owner, competition from crowd-taxis may result in a loss of services. As transport is important for covering a range of everyday needs, this has other consequences for society. The competition that crowd-taxis provide will make the traditional taxis lose their income in lucrative areas or times, as the non-taxi prices are lower than what the taxis can offer. The regulating authorities are therefore concerned that the result will be a deficiency of taxi services in certain areas (Interview 18). In Sweden several smaller communities no longer have a taxi service, because of the deregulation of the taxi market (Interview 17).

Similarly, in rural areas in Norway, in Salten and Troms, there is a lack of taxi services. In interviews carried out by Frode Longva, Oddgeir Osland and Merethe D. Leiren (2010), representatives of public authorities and the taxi industry argued that the disappearance of taxi services is related to the loss of contracts for driving patients (p. 22). In order to increase competition in competitive tenders, public authorities have allowed tour bus operators to compete for access to markets that have traditionally been in the hands of taxi operators. However, the tour bus operators do not have the same driving and coverage obligations as taxis. Tour bus companies have therefore been able to offer lower prices in competitive rounds. As a consequence, given the importance of public contracts for the revenue base of taxi owners in rural areas, taxis have ceased to exist (Interview 1). Interests representing the taxi industry, 
argue that such 'unfair' competition has negative consequences for the communities (Interviews $1 ; 5 ; 8)$. They are of the opinion that Uber, if allowed to operate without the same responsibilities than taxis, will contribute to strengthening such tendencies (Interview 17). There are also concerns related to the status of the profession. A weakening of the revenue base has resulted in a lower status and increasing recruitment issues (Longva, Osland \& Leiren, 2010, p. 22). Over the last year, the income in the taxi industry as a whole has decreased (Statistics Norway, 2015).

Others raise concerns with the crowd-taxis' lack of passenger rights. While taxi dispatchers and taxi owners have a responsibility to have wheelchair accessible vehicles, baby cribs and so on, crowd-taxis do not adhere to such regulations. Avoiding such responsibilities makes it possible for crowd-taxis to charge much lower prices than taxis (Interview 1).

However, Uber services have tried to emphasise optimism about a greener, more efficient future in order to receive political support. For example, the previous liberal City Council Commissioner in Oslo has argued, 'We need cheaper and better taxi services' (Melby in Osloby, 2015). She is of the opinion that crowd-taxis should be allowed to carry out their services, but only when pre-booked via the application. In her opinion, crowd-taxis should not be allowed to attend competitive tenders. Similarly, the Norwegian Competition Authority (2015) is optimistic about the consumer benefits and has suggested to deregulate the taxi market, removing the taxi permit and price regulation and allow for services such as Uber. However, it is disputed whether Uber represents 'greener' services than regulated taxis, as the authorities cannot enforce environmental standards on unregulated services (Interview 19).

Related to the sharing economy, there are issues of an increasing black or informal economy. Uber is no exception as the drivers do not have the taximeters, which give information about income to the authorities. However, the virtual technologies create possibilities. All passengers pay by credit card, so there is no cash in circulation, and Uber transfers payments weekly (Eggesvik, 2015). There are ways to avoid tax evasion for example, if Uber reported all transactions directly to the authorities. In Estonia there is a function in the Uber application, which lets the driver easily share such information with the authorities. Representatives of virtual transport innovations suggest abolishing current exemptions from taxes to make it easier to collect taxes. The CEO of 'Neighbour car', Even Tangen Heggernes argues, 'I think tax per transaction would be best for everyone. [...] The sharing economy makes it easy to earn money. It should be equally easy to pay taxes' (in Tobiassen, 2015).

\section{DISCUSSION}

The evidence suggests that sharing economy innovations affect the taxi market and society in different ways. For the purpose of understanding the new phenomenon of crowd-taxis in a virtual context, we start with Shield's (2003) concept of the virtual: to some extent and in certain market segments, crowd-taxis, like virtual offices, are 'taxis' in purpose and effect. The sharing economy and the mingling of demand and supply on the internet provide private drivers with available vehicle capacity and passengers the opportunity to meet. This has created competitive pressures, which the taxi industry fears. Problems arise because crowd-taxis are not regulated like traditional taxis - not because of the technology they use.

In the post-fordism service economy, researchers focusing on crowdworking expect low entry barriers to create the potential for economic development in for example rural areas. However, 
certain conditions might hamper this in the taxi market. While there is a low risk in entering the market, given that there is little capital investment or employee training, the taxi market in rural areas is diminishing. One explanation is the importance of contracts with public authorities for the revenue base. Income from public contracts covers $10-20 \%$ in the biggest cities, with some companies opting out of contract work, and 80-90\% in rural areas, where contract services dominate the market (Aarhaug, 2015). In competitive tenders taxi operators have lost contracts to tour-bus operators, which do not have the same extent of service obligations as taxis. Therefore the taxi industry already experiences competitive pressures due to other developments than the virtual innovations. Crowd-taxis increase such pressures further.

The application-based companies have the possibility to undercut prices on pre-booked trips, thereby undermining the scope for taxi services further. Researchers have found that, in general, price competition is limited in the taxi markets (Kolesnyk \& Mengshoel, 2011) and that fare elasticities are low (Rose \& Hensher, 2013). In other words, the price effects may be minor. However, Uber drivers do not have the same expenses related to for example, taximeters, uniformed vehicles, dome lights, accessible vehicles, $24 \mathrm{~h}$ service and full-time employment. It is therefore likely that crowd-taxis are able to provide a cheaper service, and to drive down the revenue for taxis. With lower prices, the demand for such transport services could increase.

Moreover, the difference between the flexibility of crowd-taxi drivers and taxi owners, who are obliged to adhere to driving and coverage obligations duties, is of importance. While the Uber driver can select which travel demand to serve, the taxi driver has to accept the trips and responsibilities as given via a taxi dispatcher. In rural areas it is unlikely that a crowd-taxi driver would be able to be fully employed. The competitive pressures from tour buses has already contributed to put pressure on the existence of taxi services in rural areas. In such situations there might be a potential in increasing the supply of transport services by letting more people drive as their second job. This way crowd-taxis could contribute to keeping the service levels up in rural areas.

It is a question whether the cloud efficiencies introduced by Uber could solve the issue of creamskimming, e.g. the algorithm plus profit maximisation will distribute taxis across 'cream' and other less profitable areas optimally. If not, in order to ensure a $24 \mathrm{~h}$ transport preparedness, the public authorities would have to come up with alternative solutions than being based on a service, which only occurs when the supplier is interested in meeting the transport demand. This is in particular an issue in rural areas. In the more lucrative markets in large cities, there might be enough drivers willing to offer services at different hours of the day, so that in practice a $24 \mathrm{~h}$ service would exist.

Related to asymmetric information, it is a question how to ensure that travelling with an Uber driver is safe and sound. A passenger does not know the qualifications or the intentions of the driver or the quality of the vehicle. In turn, the driver does not know whether the passenger is reliable. Such uncertainty is stronger for crowd-taxis than taxis, as taxi drivers have undergone courses and have good conduct. However, according to a survey carried out by the Norwegian Consumer Council (2015b), more than half of Norwegian taxi customers have had negative experiences with the taxi driver and one in four women responded that they have been afraid. In the bigger cities there have also been several lawsuits related to tax evasion among taxi drivers.

Digital technologies such as online feedback systems allow passengers to learn about the quality of drivers from prior passengers. The question is whether this is good enough for ensuring the customers' quality. Uber does for example not offer services for people with disabilities or persons without smartphones. In Norway today 20 percent of the population does not have a 
smartphone (Competition Authority, 2015, p. 2) and is therefore excluded from the web based transport innovations.

According to professionalisation theory, technology may contribute to changing the power relations in the transport sector. Navigation devices have made it less difficult for everyone to know where to drive and find the shortest route. It is therefore more difficult for taxi drivers to claim their unique expertise. The profession has consequently lost power. The weakening of the revenue base in rural areas has contributed to this tendency. The virtual technology may contribute to strengthen this propensity.

The new virtual technologies challenge the existing legal framework (for an overview, see Witt, Suzor \& Wickström, 2015). One major issue is that crowd-taxis do not contribute with covering the costs and commitments associated with regulations. Researchers focusing on crowdworking emphasise deregulation and self-regulation as a possible way of approaching such challenges. Yet re-regulation tends to go hand in hand with deregulation, aiming to correct unwanted market failures or self-regulatory outcomes.

\section{CONCLUSION}

The sharing economy has created both optimism and concerns in the transport sector. On the upside, the easy way of connecting supply and demand through virtual technologies contribute to efficiency gains in terms of utilising available capacity. It enhances competition and is customer-oriented. On the downside, there are concerns about poor transport preparedness, accessibility issues, worsened working conditions, lack of quality assurance and tax evasion. In particular the lack of a level playing field between the regulated taxi industry and the web-based crowd-taxis has created resentment all over the world. In Canada taxi drivers have taken to the streets, protesting against Uber (Austen, 2015). In New York people with disabilities are concerned with their accessibility (Dwyer, 2015). In France even Uber drivers protest against Uber (Toor, 2015).

Virtual technologies have contributed to intensify the tension between a 'universalist' perspective and a 'competitive' approach: the regulations of the taxi market provides existing taxi owners and dispatchers some protection, while requiring that they guarantee transport preparedness and that some vehicles are accessible to people with special needs. Social solidarity therefore justifies such protection. However, competition from drivers operating outside this regulation using web applications for dispatching undermines this social solidarity approach. In a competitive situation, a competitor can choose to enter only those markets that are profitable, thereby depriving the established taxi owners of the revenue to fund universal services. There are therefore concerns that this endangers the quality of transport services as well as the transport preparedness in rural areas. If society wants these services to be performed, in a competitive regime, the payment will have to be made to the service providers in a different way than today's indirect approach.

At present in Norway crowd-taxi drivers avoid costs imposed on conventional taxis through regulations. While crowd-taxis may contribute with services for example, in peak hours quality levels may also worsen: there is no guarantee that an Uber driver will choose to drive at the moment when transport is needed and an Uber driver may not be able to offer for example, a wheelchair accessible vehicle or baby crib. The probability that crowd-taxis will offer such services is currently low. 
The example of the taxi sector shows that competitive pressures and regulatory challenges also existed prior to crowd-taxis. Politicians are facing a key challenge in how to design new policies and decide whether to deregulate the taxi industry or regulate crowd-taxis. In the future, new technologies such as autonomous vehicles may further challenge the possibilities of market shares and create the need for new regulations. In the meantime, there is uncertainty about how to practice existing regulations and cases are being decided on in the courts of law. One key challenge in the 21st century is to create regulations which facilitate provision of safe and available transport services to the public, both in rural and urban areas. Another is to allow for the benefits of new technologies without creating an uneven playing field. Given the need for universal services in rural areas, balancing these competing aims is particularly challenging. 


\section{REFERENCES}

Aarhaug, J. (2015). Competitive tendering in an entry regulated market - an accident waiting to happen? European Transport Research Review, 7(17). doi:10.1007/s12544-015-0166-4

Aarhaug, J., \& Skollerud, K. (2014). Taxi: Different Solutions in Different Segments. Transportation-research-procedia. 1(1), 276-283. doi:10.1016/j.trpro.2014.07.027

Aarhaug, J., \& Skollerud, K. (2016). Taking space into account in taxi regulation (Working Document No. 50966). Oslo: Institute of Transport Economics. Unpublished, available on request.

Aarhaug, J., \& Osland, O. (2010). Drosjeløyver i nedre Buskerud (Report No. 1085/2010). Oslo: Institute of Transport Economics. Retrieved from

https://www.toi.no/publikasjoner/drosjeloyver-i-nedre-buskerud-article28654-8.html

Anderson, D. N. (2014). "Not just a taxi"? For-profit ridesharing, driver strategies, and VMT. Transportation, 41(5), 1099-1117. doi:10.1007/s11116-014-9531-8

Austen, I. (2015, December 9). Canada: Cabdrivers Stage Uber Protest. The New York Times. Retrieved from http://www.nytimes.com/2015/12/10/world/americas/canada-cabdrivers-stage-uber-protest.h tml

Ballantyne, D., \& Varey, R. (2008). The service-dominant logic and the future of marketing. Journal of the Academy of Marketing Science, 36(1), 11-14. doi:10.1007/s11747-007-0075-8

Botsman, R., \& Rogers, R. (2010). What's Mine Is Yours: The Rise of Collaborative Consumption. New York: HarperCollins.

Cohen, M., \& Sundararajan, A. (2015). Self-regulation and Innovation in the Peer-to-Peer Sharing Economy. The University of Chicago Law Review Online, 82(1), 116-133. Retrieved from

https://lawreview.uchicago.edu/sites/lawreview.uchicago.edu/files/uploads/Dialogue/Sundara rajan_Cohen_Dialogue.pdf - Available at

https://chicagounbound.uchicago.edu/uclrev_online/vol82/iss1/8/

Competition Authority. (2015). Et drosjemarked for fremtiden (Report). Bergen: Norwegian Competition Authority. Retrieved from

http://www.konkurransetilsynet.no/globalassets/filer/publikasjoner/rapporter/rapport_drosje marked-for-fremtiden.pdf - Available at https://konkurransetilsynet.no/wpcontent/uploads/2018/o8/rapport_drosjemarked-for-fremtiden.pdf

Dwyer, J. (2015, December 22). Accessibility as Challenge in Age of Uber. The New York Times. Retrieved from

http://www.nytimes.com/2015/12/23/nyregion/accessibility-as-challenge-in-age-of-uber.html? $-\mathrm{r}=\mathrm{O}$

Eggesvik, O. (2015, May 17). Ubers sjef i Norge: Skal gjøre det unødvendig for folk i sentrum å eie egen bil. Osloby. Retrieved from

http://www.osloby.no/nyheter/Ubers-sjef-i-Norge-Skal-gjore-det-unodvendig-for-folk-i-sentru m-a-eie-egen-bil-8021278.html 
Eraut, M. (1994). Developing Professional Knowledge and Competence. London: Routledge Falmer.

Fagerli, K., Strømsnes, A., \& Langli, J. C. (2000). Taxinæringen i Oslo: Fra svart til hvitt (Report). Oslo: Handelshøgskolen BI. Retrieved from http://home.bi.no/fgl9oo28/paper/Taxi_okt20oo.pdf

Felstiner, A. (2011). Working the Crowd: Employment and Labor Law in the Crowdsourcing Industry. Berkeley Journal of Employment and Labor Law, 32(1), 143-204.

doi:10.15779/Z38Z92X

Howe, J. (2006, January 6). The Rise of Crowdsourcing. Wired Magazine. Retrieved from http://www.wired.com/2006/o6/crowds/

Kellner, D., \& Thomas, A. (n.d.). Review of Rob Shields, The Virtual. Retrieved from http://www.gseis.ucla.edu/faculty/kellner/essays/reviewthevirtual.pdf - Available at https://pages.gseis.ucla.edu/faculty/kellner/essays/reviewthevirtual.pdf

Kessler, S. (2015, September 14). The "sharing economy" is dead, and we killed it. The Fast. Retrieved from

http://www.fastcompany.com/3050775/the-sharing-economy-is-dead-and-we-killed-it

Koopman, C., Mitchell, M. D., \& Thierer, A. (2014). The Sharing Economy and Consumer Protection Regulation: The Case for Policy Change (Working Paper). Arlington, VA: Mercatus Center, George Mason University. Retrieved from

http://www.researchgate.net/profile/Adam_Thierer/publication/269275998_The_Sharing_Ec onomy_and_Consumer_Protection_Regulation_The_Case_for_Policy_Change/links/5485acd 20cf2437065c9edb8.pdf

Longva, F., Osland, O., \& Leiren, M.D. (2010). Omreguleringer i drosjemarkedet - hvilke alternativer finnes og hva blir konsekvensene? [Regulation of the Norwegian taxi service industry - alternatives and consequences] (Report No. 1054/2010). Oslo: Institute of Transport Economics. Retrieved from https://www.toi.no/getfile.php?mmfileid=14053

Kolesnyk, S., \& Mengshoel, A. (2011). Kartlegging av kunders bestillingsrutiner ved bruk av taxi i Bergen (Report No. 01/11). Bergen: Centre for Applied Research at NHH. Retrieved from http://www.snf.no/Files/Filer/Publications/Rapport\%2001_11.pdf

Moe, S. (2015, May 5). Alle Haxi-sjåførene er frifunnet. E24. Retrieved from http://e24.no/digital/alle-haxi-sjaafoerene-er-frifunnet/23455690

Riaz, W. (2015, October 23). Politiet avskiltet Uber-bil. Osloby. Retrieved from http://www.osloby.no/Politiet-avskiltet-Uber-bil-820570o.html

Rose, J. M., \& Hensher, D. A. (2013). Demand for taxi services: new elasticity evidence. Transportation, 41(4), 717-743. doi:10.1007/s11116-013-9482-5

Osloby. (2015, March 20). Oslobyråd ønsker Uber velkommen. Osloby. Retrieved from http://www.osloby.no/nyheter/Oslobyrad-onsker-Uber-velkommen-7951262.html

Salanova, J. M., Romeu, M. E., \& Amat, C. (2014). Aggregated modelling of urban taxi services. Procedia - Social and Behavioral Sciences, 160, 352-361. doi:10.1016/j.sbspro.2014.12.147 
Shields, R. (2003). The Virtual. London: Routledge. doi:10.4324/9780203987186

Statistics Norway. (2015). Drosjenæringen senker farten. Retrieved from:

http://www.ssb.no/transport-og-reiseliv/statistikker/drosje/kvartal

The Consumer Council. (2015a). Nordmenn mener taxi er for dyrt. Retrieved from

http://www.forbrukerradet.no/vi-mener/2015/fpa-offentlig-2015/nordmenn-mener-taxi-er-for -dyrt/

The Consumer Council. (2015b). Over halvparten har hatt dårlige taxi-opplevelser. Retrieved from

http://www.forbrukerradet.no/vi-mener/2015/fpa-offentlig-2015/over-halvparten-har-hatt-dar lige-taxi-opplevelser/

Tobiassen, M. (2015, January 17). Derfor kan delingsøkonomien fjerne dine skattefritak. Dagens Næringsliv. Retrieved from

http://www.dn.no/grunder/2016/o1/17/1617/Skatteetaten/derfor-kan-delingskonomien-fjerne -dine-skattefritak

Tobiassen, M (2016, January 17). Få dem inn, så skal jeg slå dem. Dagens Næringsliv. Retrieved from http://www.dn.no/grunder/2016/o1/17/2209/Samferdsel/-f-dem-inn-s-skal-jeg-sl-dem

Toor, A. (2015, October 9). Even Uber drivers are now protesting against Uber in France. The Verge. Retrieved from

http://www.theverge.com/2015/10/9/9486041/uber-france-drivers-protest-paris-fare-cut

Tucker, H. (2014). Uber prices surge up to 4x normal fare in Martin Place during Sydney siege. News.com.au. Retrieved from http://www.news.com.au/technology/online/social/uber-prices-surge-up-to-4x-normal-fare-in -martin-place-during-sydney-siege/news-story/7572292956c6711f178488643d85ea7b

Witt, A., Suzor, N., \& Wickström, P. (2015). Regulating ride-sharing in the peer economy. Communication Research and Practice, 1(2), 174-190. doi:10.1080/22041451.2015.1048041

\section{APPENDIX}

\section{List of Interviews}

1 Taxi owner interests organisation, management, Oslo, 1.5h, November 2014

2 Non-taxi, management, Oslo, 2h, December 2015

3 Taxi driver, Hønefoss/Drammen, 30 min, November 2014

4 Taxi driver, Hønefoss/Drammen, 30 min, November 2014

5 Taxi driver, Hønefoss/Drammen, 30 min, November 2014

6 Taxi driver, Hønefoss/Drammen, 30 min, November 2014

7 Taxi dispatcher, management, telephone, 1h, November 2014 
8 Taxi dispatcher, management, Oslo, 1h, March 2015

9 Taxi dispatcher, management, Oslo, 1.5h, December 2014

10 Taxi dispatcher, management, telephone (30 min), January 2015

11 Taxi owner, Hønefoss/Drammen (30 min), June 2015

12 Crowd-taxi, communications director, Oslo, 1h, February 2015

13 Crowd-taxi driver, Oslo, $15 \mathrm{~min}$ in car with informant, June 2015

14 Crowd-taxi driver, Oslo, $15 \mathrm{~min}$ in car with informant, June 2015

15 Crowd-taxi driver, Oslo, 15 min in car with informant, February 2015

16 Crowd-taxi driver, Oslo, 15 min in car with informant, February 2015

17 Taxi owner interests, telephone, 30 min, January 2016

18 Akershus county, regulating authority, Oslo, 1.5h, February 2016

19 Oslo municipality, regulating authority, Oslo, 1.5h, February 2016

\section{ACKNOWLEDGEMENTS}

We would like to thank Kris Erickson, Gabriella Sanstig and Inge Sørensen for comments on earlier drafts of this paper. We are grateful to the interviewees for their time, providing information to formulate this paper.

\section{FOOTNOTES}

1. One of the representatives of the management of a taxi dispatcher was also a taxi owner. 